\title{
Pre- and Post-Natal Endotoxin Exposures: Effects on Leucocyte Ratios and Levels of IL-1 $\beta$, TNF-, Gonadotropins and Corticosterone in Female Rats
}

\section{Prenatal Ve Postnatal Endotoksin Maruziyetleri: Dişi Sıçanlarda Lökosit Oranları Ve IL-1 $\beta$, TNF- $a$, Gonadotropin Ve Kortikosteron Seviyeleri Üzerindeki Etkileri}

\author{
(1)Hilal Yıldııım', Sedat Yıldız', (1)Tuba Özgöçer² \\ 'Inonu University, Faculty of Medicine, Depertmant of Physiology, Malatya, Turkey \\ ${ }^{2}$ Harran University, Faculty of Medicine, Depertmant of Physiology Şanlıurfa, Turkey \\ Copyright@Author(s) - Available online at www.dergipark.org.tr/tr/pub/medr \\ Content of this journal is licensed under a Creative Commons Attribution-NonCommercial 4.0 International License (c) (7) ()
}

\begin{abstract}
Aim: The aim of this study is to investigate the long-term effects of prenatal and postnatal endotoxin exposure on hematological parameters, blood cytokines (TNF-a, IL-1 $\beta$ ), gonadotropins and corticosterone levels in female rats.

Material and Method: Pregnant rats were injected intraperitoneally sterile saline (SF) or endotoxin (LPS) on days 17-18 of pregnancy. Following birth, female pups were subdivided into two groups and injected either sterile saline $(S F, n=17)$ or endotoxin (LPS, $n=17)$ on postnatal day 60 and four experimental groups were formed (SF+SF, SF+LPS, LPS+SF and LPS+LPS). Blood samples were taken 4 hours after final injection. Plasma levels of IL-1 $\beta$, TNF- $\alpha$, corticosteron, LH, FSH and blood leucocyte ratios were evaluated. Results: Neutrophil \% ratio was higher but lymphocyte \% ratio was lower in SF+LPS, LPS+SF and LPS+LPS groups than SF+SF group. Corticosterone, LH and FSH levels were not different between the groups but TNF-a level of LPS+LPS groups was higher than SF+SF and LPS+SF groups. IL-1 $\beta$ level of SF+LPS group was higher than SF+SF and LPS+SF groups.

Conclusion: The results suggest that prenatal and post-pubertal endotoxin exposure programs cytokine level neutrophil and lymphocyte percentages without affecting hypothalamo-pituitary-adrenal and-gonadal axes.
\end{abstract}

Keywords: Prenatal endotoxin, postnatal endotoxin, neutrophil, lymphocyte, IL-1 $\beta$, TNF-a, corticosterone, gonadotrophins.

Öz

Amaç: Bu çalışmanın amacı doğum öncesi ve doğum sonrası endotoksin maruziyetinin dişi sıçanlarda hematolojik parametreler, kan sitokinleri (TNF-a, IL-1 $\beta$ ), gonadotropinler ve kortikosteron seviyeleri üzerindeki uzun vadeli etkilerini araştırmaktır.

Materyal ve Metot: Gebe sıçanlara gebeliğin 17-18. günlerinde intraperitoneal olarak steril salin (SF) veya endotoksin (LPS) enjekte edildi. Doğumdan sonra dişi yavrular iki gruba ayrılarak doğum sonrası 60 . günde steril salin $(S F, n=17)$ veya endotoksin (LPS, $n=17$ ) enjekte edildi ve dört deney grubu oluşturuldu (SF+SF, SF+LPS, LPS+SF ve LPS+LPS). Son enjeksiyondan 4 saat sonra kan örnekleri alındı. Plazma IL-1 $\beta$, TNF-a, kortikosteron, LH, FSH düzeyleri ve kan lökosit oranları değerlendirildi.

Bulgular: Nötrofil \% oranı SF+LPS, LPS+SF ve LPS+LPS gruplarında SF+SF grubuna göre daha yüksek ancak lenfosit \% oranı daha düşüktü. Kortikosteron, LH ve FSH düzeyleri gruplar arasında farklı değildi ancak TNF-a düzeyleri LPS+LPS gruplarında SF+SF ve LPS+SF gruplarından daha yüksekti. SF+LPS grubunun IL-1 $\beta$ düzeyi SF+SF ve LPS+SF gruplarından daha yüksekti.

Sonuç: Prenatal ve post-pubertal endotoksin maruziyetinin, hipotalamo-hipofiz-adrenal ve -gonadal eksenleri etkilemeden sitokin düzeyi, nötrofıl ve lenfosit yüzdelerini programladığı belirlenmiştir.

Anahtar Kelimeler : Prenatal endotoxin, postnatal endotoxin, nötrofil, lenfosit, IL-1ß, TNF-a, kortikosteron, gonadotropinler.

Geliş Tarihi / Received: 05.03.2021 Kabul Tarihi / Accepted: 06.05.2021

Sorumlu Yazar /Corresponding Author. Tuba Özgöçer, Harran University, Faculty of Medicine, Depertmant of

Physiology, Şanlıurfa, Turkey, E-mail: tubaozgocer@harran.edu.tr 


\section{INTRODUCTION}

There is a commensalist/mutualist balance between bacteria and the host and disruption of this balance may cause diseases in the latter. Accordingly, bacterial infections cause inflammatory reactions bystimulatingthe immune system (1) and change blood parameters, various hormonal responses, and inflammatory parameters such as interleukin 1 beta (IL-1 $\beta$ ) and tumor necrosis factoralpha (TNF-a) (2). Number and type of leukocytes may also be influenced by the bacterial infections (3).

The effects of maternal infections on the development of postnatal or adulthood infections are not well known. Available data suggest that some maternal stress factors during pregnancy may re-program offsprings development and health status of the offsprings (4). This condition known as "fetal programming" is also thought to modify the responses of the offsprings to infections later in the life $(4,5)$.

Bacterial cell wall consitituents, namely endotoxins or lipopolysaccharides (LPS), are used to mimic bacterial infection. LPS-activated inflammatory responseincreases cytokines like IL-1 $\beta$ and TNF- $\alpha$ (2) and changes leukocyte differential counts (6). This stresful maternal condition might also re-program offsprings' hypothalmo-piutitaryadrenal or-gonadal axes (HPA and HPG, respectively) and may cause changes in corticosterone or gonadotrophins. However, this response might be modified by prenatal exposure to endotoxins. Therefore, we hypothesized that prenatal exposure to endotoxins would modify responses to post-pubertal endotoxins in adult female pups in terms of hematological parameters, levels of blood TNF-a, IL-1 $\beta$, corticosterone and gonadotrophins (LH and FSH). In fact, the selected parameters were those which were either inflammation-related (hematological parameters, levels of blood TNF-a, IL-1 $\beta$ ) or stress-related (corticosterone and gonadotrophins), which were both associated with effects of endotoxine exposure.

\section{MATERIAL AND METHOD}

\section{Ethics Committee Approval}

All procedures were conducted according to the guidelines of the Animal Research Ethics Committee of Inonu University Medical Faculty (2011/A-65) and carried out according to the guiding principles of the declaration of Helsinki.

\section{Experimental Animals}

This study was conducted on female pups obtained from 10 six month-old Sprague-Dawley pregnant rats (weight: 200-250 g) were purchased from and housed in our Experimental Animal Unit (Inonu University, Malatya, Turkey). They were housed under controlled conditions ( $12 \mathrm{~h}$ light: $12 \mathrm{~h}$ dark; $22 \pm 2{ }^{\circ} \mathrm{C}$ ) and supplied with food and water ad libitum. For pregnancy to occur, 2 female and 1 male rats were kept in the same cage. Vaginal smears were taken daily at 09.00-11.00 $\mathrm{h}$ and were observed by light microscope for detection of spermatozoa to ensure a successful pregnancy. The day of observation of spermatozoa was accepted as the day 0 of pregnancy, and thereafter the animals were taken into individual cages. Injections (saline or LPS) outlined below were carried out on the day 18 of pregnancy (prenatal injection). The day of delivery was recorded and on postnatal day 21 , female pups were divided into cages, each containing 4 pups. Second injections outlined below (saline or LPS) were applied at 9 a.m on the postnatal day 60 . Exactly $4 \mathrm{~h}$ after the second injections animals were weighed, sacrificied and blood samples were taken for the determination of gonadotropins (LH, FSH), corticosterone, IL-1beta, TNFalpha, whole blood counting.

\section{Experimental Groups}

Pregnant rats were injected either saline or LPS on day 18 of the pregnancy (prenatal injection) and the pups born to these rats were injected saline or LPS on postnatal day 60 . Finally four groups of pups were formed as outlined in Table 1. Body weights of the rats were measured by scales to determine the dose of LPS. Lipopolysaccharide (LPS, Escherichia coli serotype 0111:B4, Sigma L-2630) in a volume of $0.05 \mathrm{ml}$ and at a dose of $50 \mu \mathrm{g} / \mathrm{kg}$ was prepared with physiological saline solution and was administered intraperitoneally by using an insulin injector (10). Similarly, sterile physiological saline solution $(0.9 \%$ $\mathrm{NaCl}$ ) was administered intraperitoneally at $0.05 \mathrm{ml}$ of by using an insulin injector. Experimental protocol is also esummarized in Figure 1.

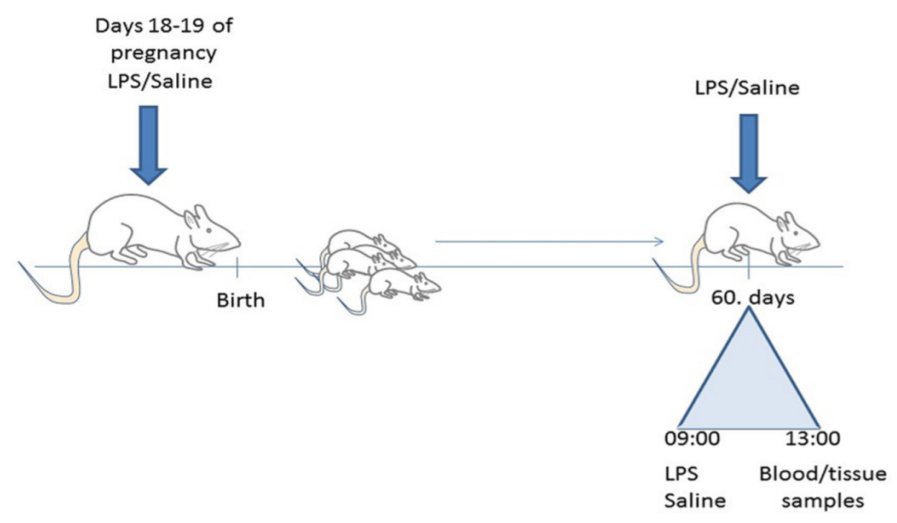

Figure 1. Experimental design. Pups born to mothers injected with LPS/ saline on the gestational day 18 were assigned into a total of 4 groups including 8-9 rat pups per group and their blood and tissue samples were taken 4 hours after the injections at 9.00 am on the postnatal day 60.

\section{Hematological Parameters}

Hematological parameters were measured manually by using Thoma slides (Marienfeld, Germany). Air dried blood smears stained with May-Grünwald-Giemsa were used to find out differential leukocytes counts (7).

\section{Serum cytokine and hormone concentrations}

Serum TNF- $a, I L-1 \beta$ and corticosterone levels were determined by rat-specific commercial ELISA kits 
(Booster, USA and Sun Red, China, respectively). Serum LH and FSH concentrations were carried out according to Pappa et al (1999) (8) as modified by Ozgocer et al., (2015) (9). Briefly, 96-well immunoplates (Nunc, Roskilde, Denmark) were coated with rat LH, rat FSH. Serum samples or standards were preincubated with primary antibodies and were then transferred into coated plates for competition with antigens on the solid phase. Plates were washed and the secondary antibody conjugated to streptavidin peroxidase was added into each well. Following washing, the color was developed by using tetramethylbenzidine as the substrate. Plates were read at $450 \mathrm{~nm}$ using a plate reader (Biotek, Synergy HT, USA). Rat LH and FSH antigens and primary antibodies (rabbit anti-rat $\mathrm{LH}$ and rabbit anti-rat FSH) were obtained from Dr. A.F. Parlow (NIDDK, NIH, USA). Secondary antibodies (goat anti-rabbit $\mathrm{IgG}$ ) conjugated to streptavidin peroxidase was purchased from Sigma (Sigma-Aldrich, Taufkirchen, Germany). Sensitivity of the assays was 1 $\mathrm{ng} / \mathrm{ml}$ for LH, $2 \mathrm{ng} / \mathrm{ml}$ for FSH and corticosterone $10 \mathrm{ng} /$ $\mathrm{ml}$ for corticosterone. Inter- and intra-assay coefficients of variations were below $8 \%$ for both $\mathrm{LH}$ and $\mathrm{FSH}$ and below $10 \%$ for corticosterone.

\section{Statistical Analysis}

IBM SPSS Statistics 22.0 program was used for statistical analysis of data of parameters of all groups. The data were given in median (min-max) or mean (SD). ShapiroWilk test was performed to examine whether or not the data met normal distribution. Kruskal-Wallis test was used for between-groups comparison of the data. On the other hand, Conover test was used for paired comparison of groups. The value of $p<0.05$ was accepted statistically significant.

\section{RESULT}

Body weights, hematologic parameters, hormonal parameters and cytokines examined in the study were presented in the following Table 2, Figure 2 and Figure 3. Body weight of the pups in LPS+SF group was significantly lower than SF+SF and SF+LPS groups but not from LPS+LPS group (Figure 2). Results regarding hematologic parameters of blood samples taken 4 hours after lipopolysaccharide (LPS) or saline (SF) injection on the postnatal day 60 are shown in Table 2. Hematocrite (\%) was highest in LPS+SF group $(p=0.012)$ but WBC count did not differ between the groups. SF+SF group tended to have lower neutrophil counts $(p=0.060)$ but neutrophil ratio (\%) was significantly lower in the SF+SF group $(p=0.001)$. Lymphocyte count was the highest in SF+LPS ( $p=0.049)$ but lymphocyte ratio $(\%)$ was highest in SF+SF group $(p=0.001)$. Basophil and monosit count and ratios were indifferent between the groups $(p>0.05)$

\section{Hormonal parameters and cytokines}

Figure 3 shows the results regarding hormonal and cytokine parameters of blood samples taken 4 hours after lipopolysaccharide (LPS) or saline (SF) injection on the postnatal day 60 . No statistical difference was observed between the groups in terms of LH, FSH and concentrations ( $p>0.05$; Figure $3(a)$, Figure $3(b)$ and Figure 3(c). Serum TNF-a level was significantly higher in LPS+LPS group than SF+SF and LPS+SF groups $(p=0.004$; Figure $3(d)$. Serum IL-1 $\beta$ level of SF+LPS group was higher than $S F+S F$, LPS+SF and LPS+LPS groups $(p=0.032$ Figure $3(e)$.

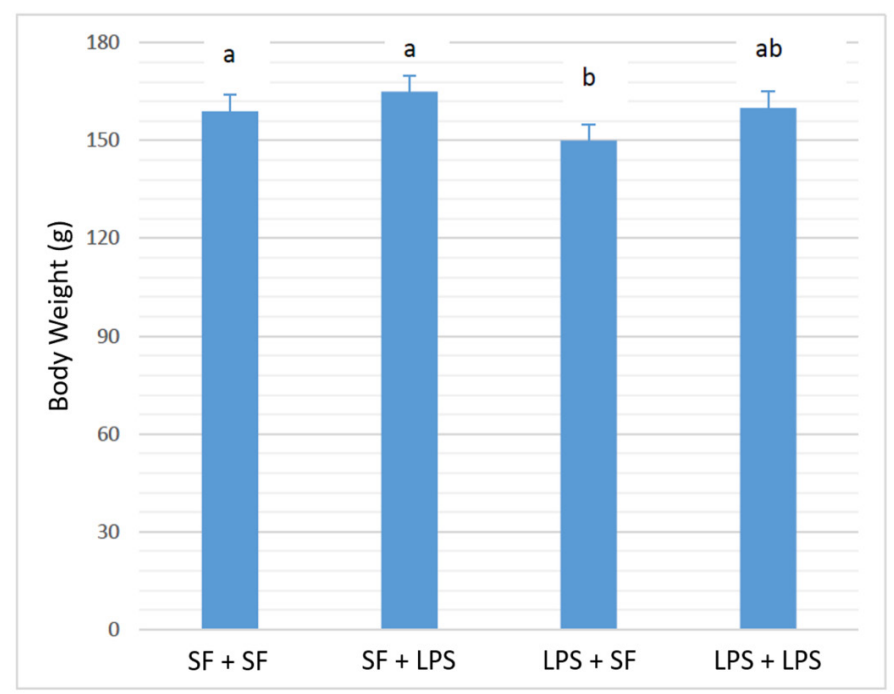

Figure 2. Effects of prenatal and postnatal LPS or saline exposure on body weight of the offsprings. The data were presented as Mean $\pm S E$ and different letters indicate a significant difference at alpha level of $p<0.05$. (a)

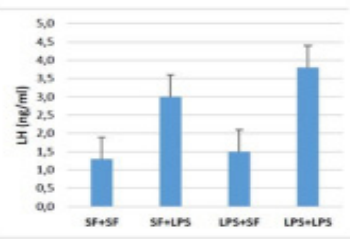

(b)

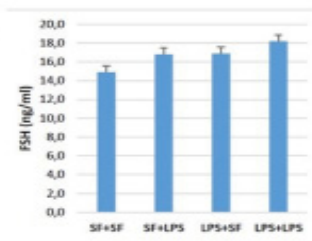

(c)

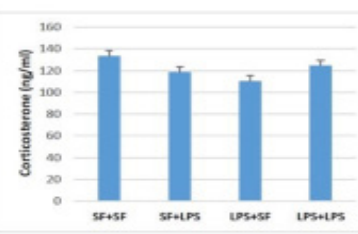

(e)

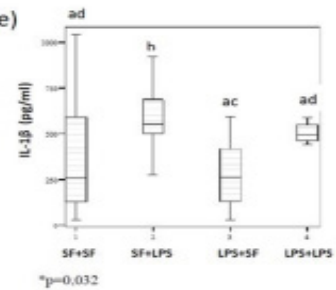

Figure 3. The Effects of LPS or saline on (a) LH, (b) FSH, (c) Corticosterone, (d) TNF-a, (e) IL-1 $\beta$ levels in blood sample taken 4 hours after lipopolysaccharide (LPS) or saline (SF) 


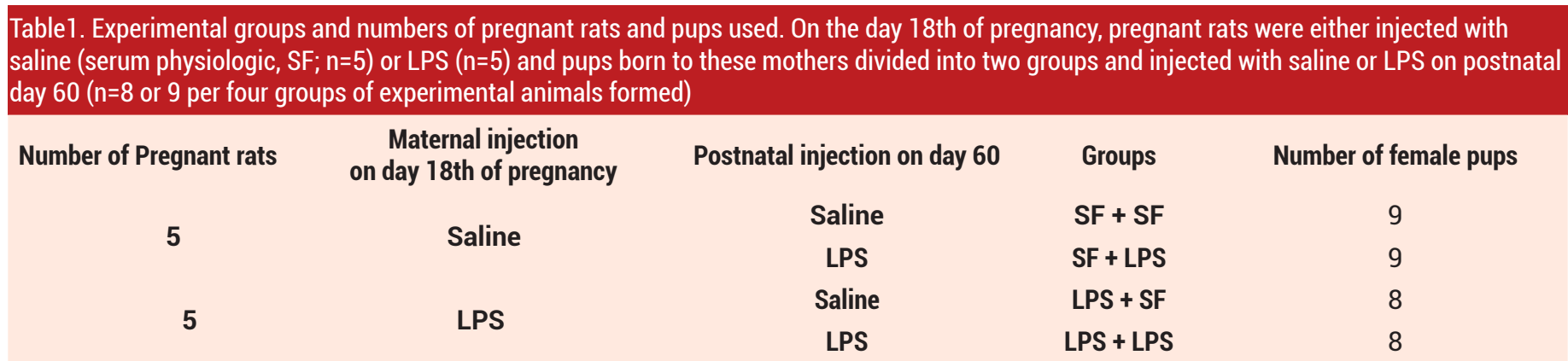

Table 2. Hematologic parameters of blood samples taken 4 hours after lipopolysaccharide (LPS) or saline (SF) injection on the postnatal day 60

\begin{tabular}{|c|c|c|c|c|c|}
\hline & $\mathrm{SF}+\mathrm{SF}$ & SF+LPS & LPS+ SF & LPS+LPS & $p *$ \\
\hline Hematocrit (\%) & $42 \pm 3^{a}$ & $41 \pm 3^{a}$ & $47 \pm 3^{b}$ & $41 \pm 4^{\mathrm{a}}$ & $.012 *$ \\
\hline WBC count (\#) & $6000 \pm 2247$ & $5733 \pm 1705$ & $8517 \pm 2998$ & $6288 \pm 2748$ & .289 \\
\hline Neutrophils count (\#) & $1059 \pm 642^{\mathrm{a}}$ & $2308 \pm 1213^{b}$ & $2644 \pm 1445^{b}$ & $2426 \pm 1580^{b}$ & .060 \\
\hline Neutrophils \% & $16 \pm 4^{a}$ & $39 \pm 11^{b}$ & $30 \pm 9^{b}$ & $34 \pm 17^{b}$ & $.001 *$ \\
\hline Lymphocyte count (\#) & $4218 \pm 1340^{\mathrm{a}}$ & $2733 \pm 947^{b}$ & $4671 \pm 1703^{a}$ & $2584 \pm 1519^{a b}$ & $.049 *$ \\
\hline Lymphocyte \% & $72 \pm 6^{a}$ & $48 \pm 11^{b}$ & $56 \pm 11 b$ & $56 \pm 17^{b}$ & $.001 *$ \\
\hline Eosinophil count (\#) & $20 \pm 31^{a}$ & $9 \pm 27^{b}$ & $76 \pm 44^{c}$ & $54 \pm 61^{\text {bc }}$ & $.017 *$ \\
\hline Eosinophil \% & $0.1 \pm 0.3^{\mathrm{a}}$ & $0.3 \pm 0.5^{\mathrm{ab}}$ & $1.0 \pm 0.6^{c}$ & $0.9 \pm 0.9^{b c}$ & $.024 *$ \\
\hline Bazofil count (\#) & $390 \pm 197$ & $344 \pm 120$ & $541 \pm 206$ & $334 \pm 234$ & .241 \\
\hline Bazofil \% & $6 \pm 1$ & $6 \pm 2$ & $7 \pm 1$ & $6 \pm 1$ & .516 \\
\hline Monosit count (\#) & $330 \pm 186$ & $341 \pm 143$ & $478 \pm 226$ & $268 \pm 219$ & .207 \\
\hline Monosit \% & $5 \pm 2$ & $6 \pm 2$ & $6 \pm 2$ & $4 \pm 1$ & .224 \\
\hline
\end{tabular}

\section{DISCUSSION}

This study showed that pups born to mothers injected with LPS during pregnancy had lower postnatal body weights. Wang et al. used daily LPS $(50 \mu \mathrm{g} / \mathrm{kg})$ injection protocol between days 13-17 of pregnancy and found out that prenatal weight decreased in male and female rats (10). Hodyl et al. (2007) injected LPS $(200 \mu \mathrm{g} / \mathrm{kg})$ on days 16 , 18,20 of pregnancy and observed decreased prenatal weight and birth weight (6). Bernardi et al. (2010) injected LPS $(250 \mu \mathrm{g} / \mathrm{kg})$ on day 21 of pregnancy and found out decreased weight on postnatal day 2 (11). Altogether, these data suggests that prenatal maternal LPS injections generally decreases body weights of pups. On the other hand, it has been showed that injection of $0.12 \mu \mathrm{g} / \mathrm{g}$ LPS on day 17 pregnancy did not affect weight of pup in the first months following birth (12) or even increased body weight (13). However, in these two studies, the dose of LPS was either very low (12) or very high (13). It could be speculated that different doses of LPS might have triggered distinct immune mechanisms affecting body wieght regulation axes in opposing ways (14). It is also known that the day of pregnancy also modifies responses given to LPS injections (15).

In this study, hematocrite value differed between the experimental groups. It was the highest in LPS+SF group, suggested a prenatal programming for hematocrite value. Furthermore, this programming appears to be obscured by the second LPS injection (LPS+LPS group). Similar hematocrite levels in SF+SF group and SF+LPS group strengthens this hypothesis. In a study carried out by Kao et al. (2006), LPS was injected at $10000 \mu \mathrm{g} / \mathrm{kg}$ dose and blood samples were taken at $0.5,1,2,3,4,5$ and 6 hours after the injection. Hematocrite value decreased within the first 1 hour after injection but then it returned to normal level (16). When the data of the present study were examined in this perspective (SF+LPS group), it could be considered that hematocrite values increased and then returned to normal level in blood samples taken at 4th hour after postnatal LPS injection.

In this study, prenatal and/or postnatal immune stimulations by LPS increased neutrophil rate (\%) but decreased lymphocyte ratio (\%). Similarly, Hodly et al. (2007), determined that lymphocyte count decreased significantly in 4 hours after LPS injection on the postnatal day 50 following prenatal LPS administration (on gestational days 16, 18, and 20) without influencing neutrophil count. On the other hand, Doursout et al. (2013), found that neutrophil count was the highest 6 hours after male rats were injected with $35000 \mu \mathrm{g} / \mathrm{kg}$ LPS (17). In the 
present study, LPS injections were determined to increase neutrophil count or rate (\%) both in the acute period and in the long term. In that respect, increased neutrophil count in the group not receiving the second LPS injection (i.e. LPS+SF group) suggests a prenatal programming. In a study conducted by Zager et al. (2013) (18), they injected LPS to rats on the prenatal day 17 and found that their neutrophil activities did not change on the postnatal day 70 , and concluded it had no impact on neutrophil-mediated innate immunity. On the contrary, in the present study, a single dose of LPS injection in the prenatal period seemed to permanently program program permanently the number and ratio of defense cells in the pups during postnatal period. In this context, while neutrophil percentage was two times higher, lymphocyte percentage decreased by $1 / 3$. Increased neutrophil count in the present study might be due to delayed apoptosis. This might be supported by the fact that increased neutrophil lifespan might be due to delayed apoptosis $(19,20)$. In fact, exposure to LPS was determined to delay neutrophil apoptosis and to increase neutrophil count $(21,22)$. It seems crucial to conduct further investigation for the effects of prenatal LPS injection on the cascades of apoptosis.

In the present study, corticosterone level was not found to be different in both prenatal and postnatal period in LPS or saline groups. Hodly et al. (2007), stated that LPS injection of $200 \mu \mathrm{g} / \mathrm{kg}$ on the prenatal day 20 increased prenatal corticosterone level (6). In the one study conducted, they found that prenatal LPS injection did not affect serum corticosterone level of rat pups (23). However, in another study injected $50,300,500 \mu \mathrm{g} / \mathrm{kg}$ doses of LPS to rats on the prenatal days 15, 16, and 17 and found out that higher doeses increased but lower doses did not affect corticosterone levels on postnatal days 40 and 80 (24). Accordingly, the dose used in the present study was equal to the low dose of LPS applied by Enayati et al. (2012) suggesting that at lower doses of LPS, prenatal injections does not affect corticosterone levels during postnatal period.

Gonadotropin secretion in the adulthood was not affected by pre- or post-natal endotoxin exposures. This might be due to negative and postive feedback effects of hypothalamo-pituitary-gonadal axis. Thus, any possible change in LH or FSH was probably rectified by the feedback effects governed by the hypothalamus. By the time the second injection of LPS was carried out, all female pups had already reached puberty. This suggest that they had a fully functional HPG axis governing these feedback mechanisms. In this study, postnatal, but not prenatal, LPS injections increased TNF- $\alpha$ and IL-1 $\beta$ levels. It is known that LPS injections increases both parameters immediately following injections. For example, LPS injections at 100 $\mu \mathrm{g} / \mathrm{kg}$ dose level increased TNF- $\alpha$ and IL- $1 \beta$ levels 3 hours post-injection (16). Lasala and Zhou (2007) injected $500 \mu \mathrm{g} / \mathrm{kg}$ LPS or saline on the prenatal day 18 and took blood samples of pups born from these rats 2 hours postinjection of LPS or saline on the postnatal day 21 (25). They observed that TNF- $\alpha$ and IL-1 $\beta$ levels were significantly higher in groups receiving postnatal LPS following prenatal saline (25). Similarly, rat pups which had maternal prenatal exposure to LPS $(200 \mu \mathrm{g} / \mathrm{kg})$ had increased TNF- $a$ and IL$1 \beta$ levels 4 hours post-injection on postnatal day 50 (6). On the other hand, Solati et al., reported that 1,5 , and $10 \mu \mathrm{g} / \mathrm{kg}$ doses of LPS administered on the prenatal day 10 did not cause any change in TNF- $\alpha$ and IL- $1 \beta$ levels of male rats on the postnatal day 21 (26). Dose of LPS used in the present study is known to induce immune response $(10,24,27-29)$. On the other hand, the dose of prenatal LPS used by Hodly et al. was higher but that of Solati et al. was lower than the dose used in the present study (6). Therefore, it is might be possible that postnatal cytokine response does not occur if the dose administered in prenatal period is lower than $200 \mu \mathrm{g} / \mathrm{kg}$. In a study conducted in humans, induction of second trimester placental tissue with endotoxin has been reported to provide tolerance to repeated ednotoxins (30). In a study conducted in mice, it was reported that exposure to endotoxins such as LPS during fetal development may be protective against an inflammatory disease in adulthood (31).

\section{CONCLUSION}

In conclusion, the present study suggests that (1) a prenatal programming against endotoxin immune challenge occurred in terms of body weights of pups and percentages of neutrophils and lymphocytes, that (2) postnatal endotoxin challenge increases TNF- $\alpha$ and IL- $1 \beta$ levels, but pre- and post-natal challenges does not appear to influencehypothalamo-pituitary-adrenal and-gonadal axes at the LPS doses applied in the current study.

Financial disclosures: All authors declare no financial support.

Conflict of Interest: The authors declare that they have no competing interest.

Ethical approval: All procedures were conducted according to the guidelines of the Animal Research Ethics Committee of Inonu University Medical Faculty (2011/A65) and carried out according to the guiding principles of the declaration of Helsinki.

\section{REFERENCES}

1. Iwasaki A, Medzhitov R. Regulation of adaptive immunity by the innate immune system. Science. 2010;327:291-5.

2. Mohamadin AM, Elberry AA, Elkablawy MA, et al. Montelukast, a leukotriene receptor antagonist abrogates lipopolysaccharide-induced toxicity and oxidative stress in rat liver. Pathophysiology. 2011;18:235-42.

3. Dong HP, Chunag IC, Wang DC, et al. Lipopolysaccharidestimulated leukocytes contribute to platelet aggregative dysfunction, which is attenuated by catalase in rats. Kaohsiung J Med Sci. 2010;26:584-92.

4. Remacle C, Bieswal F, Bol V, et al. Developmental programming of adult obesity and cardiovascular disease in rodents by maternal nutrition imbalance. Am J Clin Nutr. 2011;94(6 Suppl):1846S-52S. 
5. Reusens B, Theys N, Dumortier O, et al. Maternal malnutrition programs the endocrine pancreas in progeny. Am J Clin Nutr. 2011;94(6 Suppl):1824S-9S.

6. Hodyl NA, Krivanek KM, Lawrence E, et al. Prenatal exposure to a pro-inflammatory stimulus causes delays in the development of the innate immune response to LPS in the offspring. J Neuroimmunol. 2007;190:61-71.

7. Brahimi M, Osmani S, Arabi A, E, et al. The estimation of platelet count from a blood smear on the basis of the red cell: platelet ratio. Turk J Haematol. 2009;26:21-4.

8. Pappa A, Seferiadis K, Marselos M, et al. Development and application of competitive ELISA assays for rat LH and FSH. Theriogenology. 1999;51:911-26.

9. Ozgocer $\mathrm{T}$, Yildiz $\mathrm{S}$, Elbe $\mathrm{H}$, et al. Endotoxin exposure and puberty in female rats: the role of nitric oxide and caspase-1 inhibition in neonates. Can J Physiol Pharmacol. 2015;93:603-14.

10. Wang $H$, Yang LL, Hu YF, et al. Maternal LPS exposure during pregnancy impairs testicular development, steroidogenesis and spermatogenesis in male offspring. PLoS One. 2014;9:e106786.

11. Bernardi MM, Kirsten TB, Matsuoka SM, et al. Prenatal lipopolysaccharide exposure affects maternal behavior and male offspring sexual behavior in adulthood. Neuroimmunomodulation. 2010;17:47-55.

12. Golan HM, Lev V, Hallak M, et al. Specific neurodevelopmental damage in mice offspring following maternal inflammation during pregnancy. Neuropharmacology. 2005;48:903-17.

13. Gao $M$, Zhang $X$, Chen $X$, et al. Prenatal exposure to lipopolysaccharide results in local RAS activation in the adipose tissue of rat offspring. PLoS One. 2014;9:111376.

14. Chen K, Geng S, Yuan R, et al. Super-low dose endotoxin preconditioning exacerbates sepsis mortality. EBioMedicine. 2015;2:324-33.

15. Wei YL, Li XH, Zhou JZ. Prenatal exposure to lipopolysaccharide results in increases in blood pressure and body weight in rats. Acta Pharmacol Sin. 2007;28:6516.

16. Kao SJ, Wang D, Lin HI, et al. N-acetylcysteine abrogates acute lung injury induced by endotoxin. Clin Exp Pharmacol Physiol. 2006;33:33-40.

17. Doursout MF, Schurdell MS, Young LM, et al. Inflammatory cells and cytokines in the olfactory bulb of a rat model of neuroinflammation; insights into neurodegeneration? J Interferon Cytokine Res. 2013;33:376-83.

18. Zager A, Pinheiro ML, Ferraz-de-Paula V, et al. Increased cell-mediated immunity in male mice offspring exposed to maternal immune activation during late gestation. Int Immunopharmacol. 2013;17:633-7.
19. Luo D, Schowengerdt KO, Jr, Stegner JJ, et al. Koenig JM. Decreased functional caspase-3 expression in umbilical cord blood neutrophils is linked to delayed apoptosis. Pediatr Res. 2003;53:859-64.

20. Von Dadelszen P, Watson RW, Noorwali F, et al. Maternal neutrophil apoptosis in normal pregnancy, preeclampsia, and normotensive intrauterine growth restriction. Am J Obstet Gynecol. 1999;181:408-14.

21. Kramer BW, Kallapur SG, Moss TJ, et al. Modulation of fetal inflammatory response on exposure to lipopolysaccharide by chorioamnion, lung, or gut in sheep. Am J Obstet Gynecol. 2010;202:77 1-9.

22. Triantafilou M, Triantafilou $K$. The dynamics of LPS recognition: complex orchestration of multiple receptors. $J$ Endotoxin Res. 2005;11:5-11.

23. Williams CL, Teeling JL, Perry VH, et al. Mouse maternal systemic inflammation at the zygote stage causes blunted cytokine responsiveness in lipopolysaccharide-challenged adult offspring. Bmc Biol. 2011;9.

24. Enayati M, Solati J, Hosseini $M H$, et al. Maternal infection during late pregnancy increases anxiety- and depressionlike behaviors with increasing age in male offspring. Brain Res Bull. 2012;87:295-302.

25. Lasala N, Zhou H. Effects of maternal exposure to LPS on the inflammatory response in the offspring. $J$ Neuroimmunol. 2007;189:95-101.

26. Solati J, Hajikhani R, Rashidieh B, et al. Effects of prenatal lipopolysaccharide exposure on reproductive activities and serum concentrations of pituitary-gonadal hormones in mice offspring. Int J Fertil Steril. 2012;6:51-8.

27. Bernardi MM, Teixeira, L. P., Ligeiro-de-Oliveira, A. P., et al. Neonatal lipopolysaccharide exposure induces sexually dimorphic sickness behavior in adult rats. Psychology \& Neuroscience. 2014;7:113-23.

28. Elovitz MA, Brown AG, Breen $K$, et al. Intrauterine inflammation, insufficient to induce parturition, still evokes fetal and neonatal brain injury. Int J Dev Neurosci. 2011;29:663-71.

29. Hodyl NA, Krivanek KM, Clifton VL, et al. Innate immune dysfunction in the neonatal rat following prenatal endotoxin exposure. J Neuroimmunol. 2008;204:126-30.

30. Kim ML, Maloney C, Klimova N, et al. Repeated lipopolysaccharide exposure leads to placental endotoxin tolerance. Am J Reprod Immunol. 2019;81:13080.

31. Banfield E, Fulton W, Burd I, Kovler ML, Sodhi CP, Hackam DJ. The role of in utero endotoxin exposure in the development of inflammatory bowel disease in mice. Am J Reprod Immunol. 2020;84:13302. 